\title{
Carbon stocks for different land cover types in Mainland Tanzania
}

\author{
Ernest William Mauya ${ }^{*}$, Wilson Ancelm Mugasha², Marco Andrew Njana ${ }^{3}$, Eliakimu Zahabu ${ }^{2,3}$ \\ and Rogers Malimbwi ${ }^{2}$
}

\begin{abstract}
Background: Developing countries participating in the mitigation mechanism of reducing emissions from deforestation and forest degradation (REDD+), are required to establish a forest reference emission level (FREL), if they wish to seek financial support to reduce carbon emissions from deforestation and forest degradation. However, establishment of FREL relies heavily on the accurate estimates of carbon stock as one of the input variable for computation of the emission factors (EFs). The product of an EF and activity data, such as the area of deforestation, results in the total emissions needed for establishment of FREL. This study presents the carbon stock estimates for different land cover classes based on an analysis of Tanzania's national forest inventory data generated through the National Forest Resources Monitoring and Assessment (NAFORMA).

Results: Carbon stocks were estimated in three carbon pools, namely aboveground, belowground, and deadwood for each of the three land cover classes (i.e. Forest, non-forest, and wetland). The weighted average carbon stock was $33.35 \mathrm{t} \mathrm{C} \mathrm{ha}^{-1}$ for forest land, $4.28 \mathrm{t} \mathrm{ha}^{-1}$ for wetland and $5.81 \mathrm{t} \mathrm{ha}^{-1}$ for non-forest land. The uncertainty values were $0.9 \%$ for forest land, $11.3 \%$ for wetland and $1.8 \%$ for non-forest land. Average carbon stocks for land cover sub-classes, which make up the above mentioned major land cover classes, are also presented in our study.

Conclusions: The values presented in this paper correspond to IPCC tier 3 and can be used for carbon estimation at the national scale for the respective major primary vegetation type for various purposes including REDD+. However, if local based estimates values are needed, the use of auxiliary data to enhance the precision of the area of interest is recommended.
\end{abstract}

Keywords: Carbon stock, REDD+, FREL, Emission factor, Uncertainty

\section{Background}

The significance of forests, particularly tropical forests, in the global carbon cycle has led to the consideration and recognition of forest-based climate change mitigation measures in the international climate negotiations, agreements and policy frameworks. Accordingly, to date a number of agreements have been reached [1]. Mostly notably, is the adoption of the Bali Action/roadmap in 2007 at the 13th Conference of Parties (COP13) and the subsequent recognition of REDD+ scheme, which is an

\footnotetext{
*Correspondence: mauya@sua.ac.tz

${ }^{1}$ Department of Forest Engineering and Wood Sciences, College of Forestry, Wildlife and Tourism, Sokoine University of Agriculture, Box 3012, Morogoro, Tanzania

Full list of author information is available at the end of the article
}

initiative referring to reducing emissions from deforestation and forest degradation [2]. Essentially, REDD+ involves implementation of a variety of policy approaches and incentive plans to the activities related with reduction in deforestation and forest degradation, as well as forest conservation, sustainable management of forests and the enhancement of forest carbon stocks in the tropical forests [3]. This mechanism has been accepted as a low-cost and promising approach for mitigating climate change [4] that will also secure many ecological functions of forests, including biodiversity conservation and provision of a number of ecosystem services.

The interest among developing countries to prepare for implementation of REDD+ projects, and in testing the potential mechanisms, has increased tremendously since 
the initial discussions under UNFCCC in 2005. However, in order to effectively implement REDD + at the national level, countries are required to develop four key components if they aim to undertake REDD+ activities and to be eligible for financial compensation [5]: (1) a national strategy or action plan; (2) a national forest reference emission level (FREL) and/or forest reference level (FRL); (3) a robust and transparent national forest monitoring system for Measurement, Reporting and Verification (MRV) of the REDD+ activities; and (4) a system for providing information on how the safeguards are addressed or respected. Forest reference emission level (FREL) being among the four key elements of the REDD+ is defined as the benchmark for carbon emissions against which a country's performance in implementing REDD+ activities can be assessed and credited [1]. However, estimation of carbon emission as key variables for setting up FREL, requires information on activity data (AD) which refers to the area of forest change (in hectare), e.g., forest converted to grassland or forest converted to cropland and Emission Factors (EF) which relates to the carbon stock change estimations per unit of activity (in carbon per hectare) [6, 7]. To ensure that there is consistency in estimation of carbon emission, the Intergovernmental Panel on Climate Change (IPCC) had provided three hierarchical tiers for reporting the different levels of detail and accuracy. The Tier 1 approach employs the default emission factors provided in the IPCC Guidelines while Tier 2 approach uses country-specific emission factors. On the other hand, Tier 3 approach uses higher order methods including models and inventory measurement systems tailored to address national circumstances, repeated over time, and driven by high-resolution activity data and disaggregated at sub-national to fine grid scales [10]. The IPCC recommends using higher Tiers for the measurement of important sources and sinks. Tier 2 or 3 methods are regarded as higher tiers since they provide the desired level of accuracy for important components of the greenhouse gas (GHG) inventory. However, higher Tier methods require more data and are more expensive, because they involve monitoring of local variables [8]. This causes a challenge to many of the REDD+ countries due to the lack of the data from continuous National Forest Inventories (NFI) which can support estimation of EF using higher Tier approaches.

Mainland Tanzania, unlike many other developing countries, has wealth of up to-date NFI data that can support estimation of EF. The first NFI in Mainland Tanzania was implemented between 2009 and 2014 through National Forest Resources Monitoring and Assessment (NAFORMA) Project. The NFI covered different land cover types including different vegetation and land use types where the three IPCC carbon pools of aboveground biomass (AGB), belowground biomass (BGB) and dead wood biomass (DWB) were assessed [9]. This allows for land cover specific estimation of emissions of greenhouse gas and reduces uncertainties. This is in line with IPCC guidelines which emphasize that estimation and reporting of greenhouse gases should be complete by considering all land covers [10]. A quarter of all inventoried plots are permanent sample plots for the purpose of repeated measurement over time. Irrespective of such initiatives, this paper is the first attempt to document carbon densities for different land cover type using the NFI data. Such information is important for the ongoing REDD+ reporting activities as well as for conventional objectives related with sustainable forest management.

Furthermore, according to IPCC [10], for complete inventory of greenhouse gas emissions, uncertainties should be estimated at different spatial scales as well as for the component parts such as carbon densities, emission factors, activity data and other estimation parameters for each category. Therefore, in line with this, our study also reports the uncertainty of carbon stocks for different land cover sub-classes.

\section{Methods \\ Study area}

The United Republic of Tanzania is a union of Mainland Tanzania and Zanzibar, it is located between longitude $29^{\circ}$ and $41^{\circ}$ East and Latitude $1^{\circ}$ and $12^{\circ}$ South. Tanzania mainland is endowed with a wide range of natural resources. The country has a very diverse climate, depending on altitude and latitude. The mean annual rainfall varies from below 500 to over $2000 \mathrm{~mm}$ per annum. The rainfall for the large part of the country is bimodal with short rains from October to December and long rains from March to May. The main forest types include deciduous miombo woodlands in the western, central and southern parts of the country, Acacia-Commiphora woodlands in the northern regions, coastal forests and woodland mosaics in the east, mangrove forests along the coast of the Indian Ocean, and closed canopy forests, which grow on the ancient mountains of the Eastern Arc, along the Albertine Rift close to Lake Tanganyika in the west, and on the younger volcanic mountains in the north and central parts of the country [11].

Based on the recently land use land cover (LULC) change analysis for Mainland Tanzania there are four primary land cover classes of (1) forest, (2) non-forest, (3) water and (4) wetlands (Table 1 and Fig. 1). Each primary class consists of several land cover sub-classes. In this regard 'Forest' means an area of land with at least 0.5 ha, with a minimum tree crown cover of $10 \%$ or with existing tree species planted or natural having the potential of attaining more than $10 \%$ crown cover, and with trees 
Table 1 Classification of land cover types in Mainland Tanzania

\begin{tabular}{ll}
\hline Land cover sub-class & Primary class \\
\hline Forest: Plantation & Forest \\
Forest: Mangrove & Forest \\
Forest: Humid montane & Forest \\
Forest: Lowland & Forest \\
Woodland: Closed (>40\%) & Forest \\
Woodland: Open (10-40\%) & Forest \\
Cultivated land (Wooded crops): Mixed tree cropping & Forest \\
Cultivated land (Wooded crops): Wooded crops & Forest \\
Woodland (Wooded crops): Scattered cropland (Unspeci- & Forest \\
fied density) & \\
Bushland: Thicket & Forest \\
Bushland: Thicket with emergent trees & Forest \\
Bushland: Dense & Non forest \\
Bushland: Emergent trees & Non forest \\
Bushland: Open & Non forest \\
Bushland: Scattered cultivation & Non forest \\
Cultivated land: Agro-forestry system & Non forest \\
Cultivated land: Grain crops & Non forest \\
Cultivated land: Herbaceous crops & Non forest \\
Grassland: Bushed & Non forest \\
Grassland: Open & Non forest \\
Grassland: Scattered cropland & Non forest \\
Grassland: Wooded & Non forest \\
N/A & Non forest \\
Open land: Bare soil & Non forest \\
Open land: Rock outcrops & Non forest \\
Open land: Salt crusts & Non forest \\
Other areas & Non forest \\
Water: Inland water & Wetland \\
Water: Swamp & Wetland \\
\hline
\end{tabular}

which have the potential or have reached a minimum height of $3 \mathrm{~m}$ at maturity in situ [12].

\section{Sampling design}

The data used for estimation of carbon stocks presented in this paper were based on the Mainland Tanzania NFI data which is commonly referred as NAFORMA, carried out from 2009 to 2014. The NFI was developed based on double sampling for stratification and optimal allocation of plots. The first-phase sample consists of clusters of plots laid on a $5 \times 5 \mathrm{~km}$ grid over mainland Tanzania. The first-phase clusters were stratified based on a combination of three criteria namely; predicted growing stock, time consumption for cluster measurements and slope of the terrain. At national level, the first-phase clusters were assigned to 18 pre-defined strata according to the three criteria [see 13, 14]. Within each stratum, second-phase samples of clusters were selected using optimal allocation [15] with cost functions tailored for each stratum using a simulation approach described in Tomppo, Malimbwi, Katila, Mäkisara, Henttonen, Chamuya, Zahabu and Otieno [13]. As a result, greater sampling intensity was allocated to strata with more variation and larger predicted growing stock and less sampling intensity to strata with less variation and smaller predicted growing stock. The distributions of the second phase plots within the entire Tanzania is presented in Fig. 2. Ten plots per cluster were used for each stratum (Fig. 3). The distance between plot centers within a cluster was $250 \mathrm{~m}$, which translates to $1280 \mathrm{~m}$ cluster lengths in east-west and north-south directions.

Plot cluster design aimed to increase efficiency during the forest inventory [16]. The sample plots were nested whereby they included 1, 5, 10 and 15 m radius concentric plots (Fig. 4). In uneven-aged natural forest stands, the number of small trees is much higher than the number of large trees. Therefore, to make the sampling efficient, small trees were measured within small sub-plots and large trees were measured within large sub-plots.

\section{Data collection}

Within each plot, trees were measured for diameter at breast height (dbh, $1.3 \mathrm{~m}$ above soil surface) using caliper and identified for species [16]. The minimum dbh of trees measured within each nested concentric circle are specified in Fig. 4. Within $15 \mathrm{~m}$ radius, dead woods $(\geq 5 \mathrm{~cm})$ were also measured for length and diameter at their terminal ends. The plot size considered were of $15 \mathrm{~m}$ radius ( $0.07 \mathrm{ha})$ and minimum diameter stem was $5 \mathrm{~cm}$ until $14^{\text {th }}$ May 2011 when adjustments were made to minimum diameter of $10 \mathrm{~cm}$ and plot radius of $10 \mathrm{~m}$ (0.031 ha) in order to improve data collection speed. For all sample plots, slope was recorded. Plot radius was corrected for slope when slope exceeded $5 \%$.

\section{Land cover sub-classes expansion factors}

Estimation of carbon stock was based on plot layout design of the NFI described earlier. Accordingly, it was necessary to calculate Expansion Factor $(E x F)$ for each respective stratum since simple mean of carbon stock would ignore the nature of the sampling design upon which the data were collected. The $E x F$ describes the area in which a sample plot represents in each stratum. Since first phase sampling units were distributed proportionally to stratum area, the area of the stratum $p\left(A_{p}\right)$ was estimated as follows:

$$
\hat{\mathrm{A}}=\mathrm{A} * \frac{\mathrm{n}_{\mathrm{p}}}{\mathrm{n}_{1}}
$$




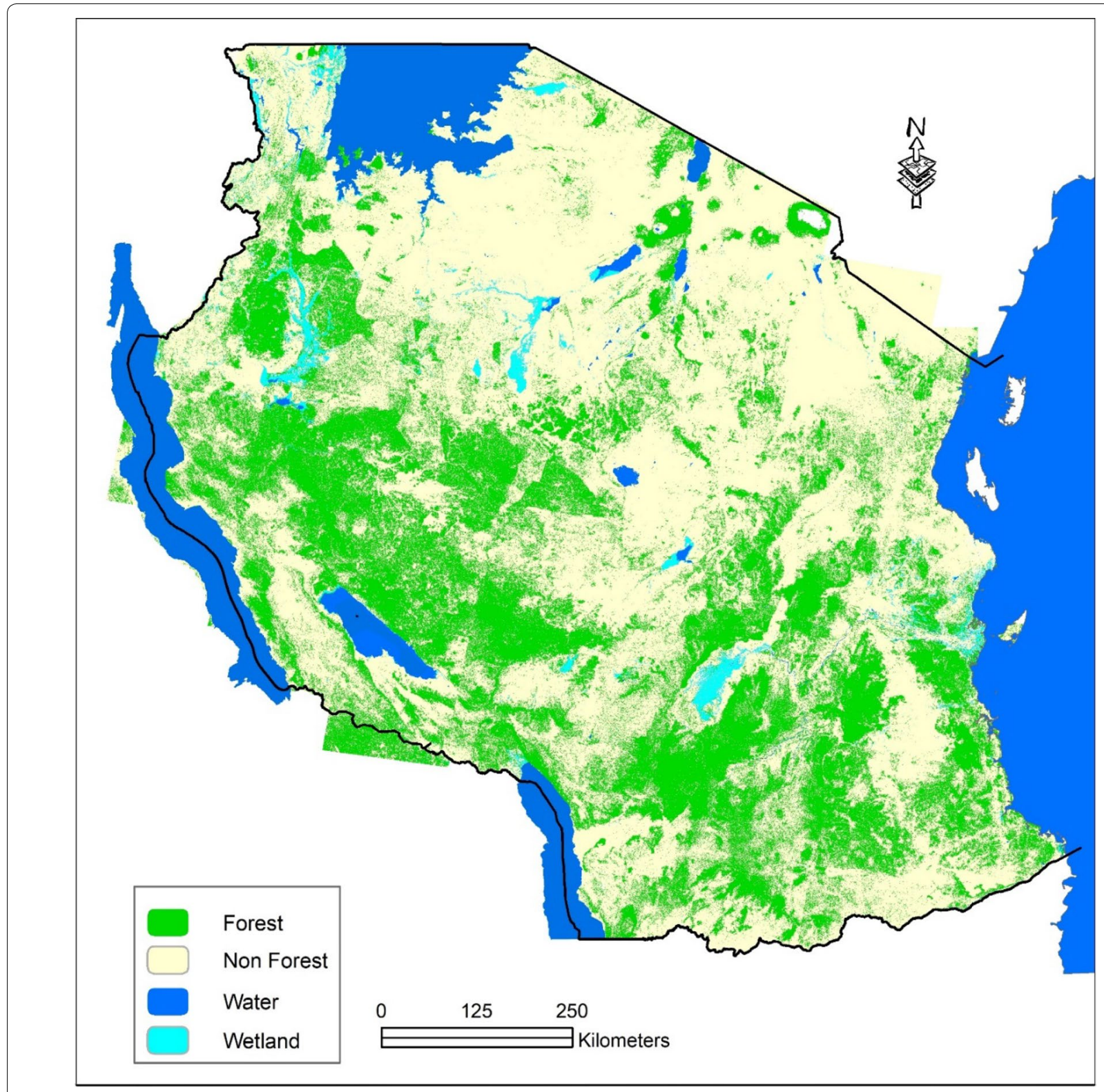

Fig. 1 Distribution of the four primary land cover classes

where: $n_{p}$ is number of first phase plots in stratum $p$ (ha); $n_{1}$ is total number of first phase plots; and $A$ is total inventory area (Mainland Tanzania area (ha)). Practical sequences of computation are shown below and further described in Tomppo, Malimbwi, Katila, Mäkisara, Henttonen, Chamuya, Zahabu and Otieno [13].

Plot area $E x F$ of stratum $p$ was computed as follows

$$
E x F_{p}=\frac{\hat{\mathrm{A}}_{\mathrm{p}}}{\mathrm{n}_{\mathrm{p}}}
$$

where: $\hat{A}_{p}$ is area of stratum $p$; and $n_{p}$ total number of plots observed in stratum $p$.

Consider $n_{k, p}$ number of plots of landcover sub-class $k$ falling in stratum $p$. The area $\hat{A}_{k p}$ of landcover sub-class $k$ in stratum $p$ was computed as:

$$
\hat{\mathrm{A}}_{\mathrm{kp}}=\sum_{k \varepsilon p} \mathrm{n}_{\mathrm{k}, \mathrm{p}} * E x F_{P}
$$

where: $n_{k, p}$ number of plots of land cover sub-class $k$ in stratum $p$; and $E x F_{p}$ is Expansion Factor of stratum $p$. 


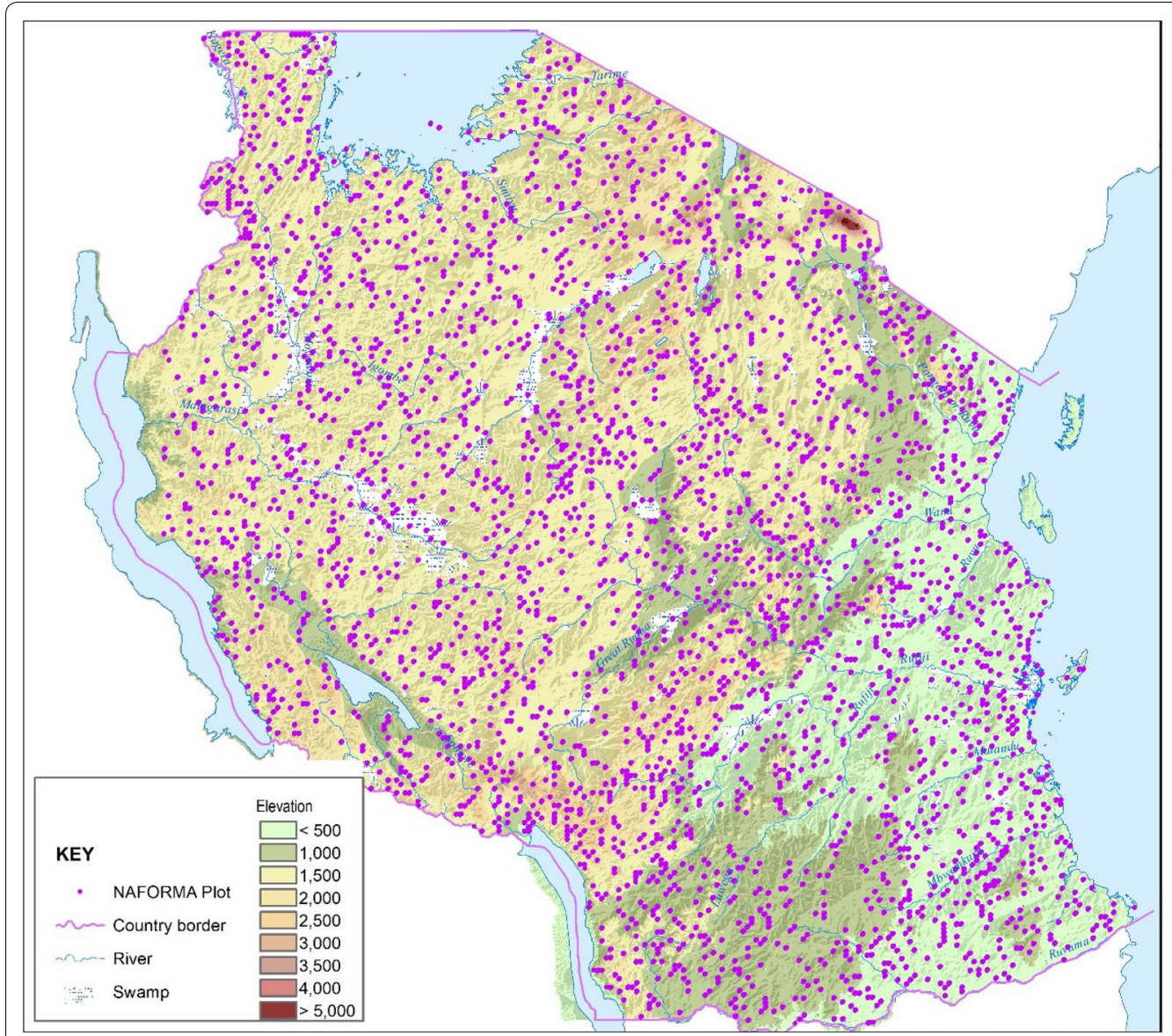

Fig. 2 Distribution of sample plots in Mainland Tanzania

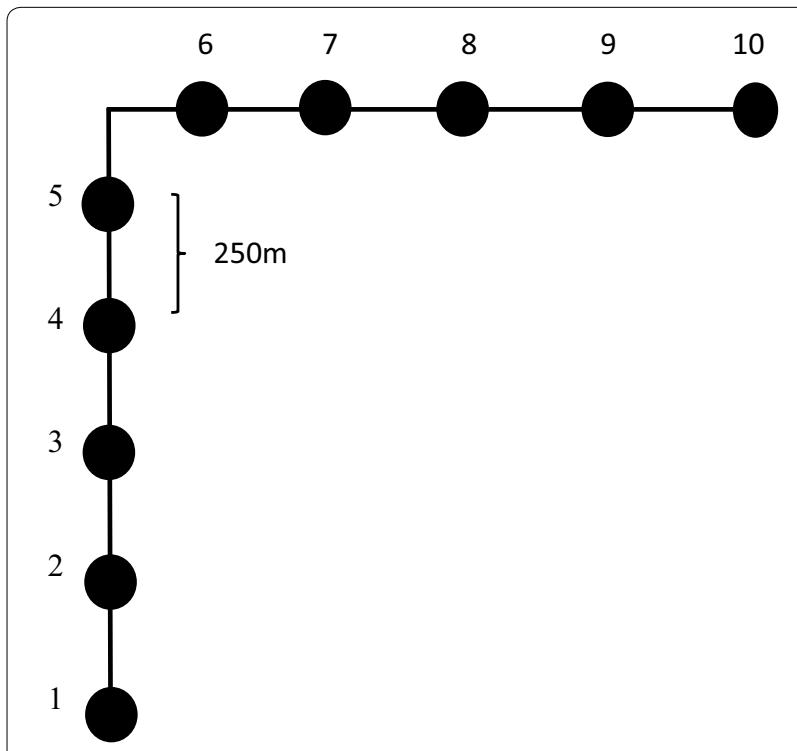

Fig. $3 \mathrm{NFI}$ cluster design (black solid circles = plot)
Area of land cover sub-class $k$ in the country is the summation of areas of land cover sub-classes $k$ found in each stratum, i.e. $\hat{A}_{k}=\hat{A}_{k 1}+\hat{A}_{k 2}+\hat{A}_{k 3}+\ldots . \hat{A}_{k p}$ where $k p$ is land cover sub-class $k$ in stratum $p$.

\section{Estimation of tree and deadwood carbon values Tree $A G B$ and $B G B$}

The AGB and BGB values of each measured tree in sample plot were estimated directly using appropriate allometric biomass models presented in Malimbwi et al. [17], URT [18] and tabulated further in Appendix 1. The models are based on the sample trees covering different land cover types in Mainland Tanzania. The plot levels values were then scaled up to per hectare level. Biomass models for few land cover types such as Open land: Salt crusts, Water: Inland water and tree species such as Dalbergia melanoxylon, Grevillea robusta, and Eucalyptus spp., were lacking. In such cases, volume models were used to compute volume which was then converted to biomass using appropriate species-specific wood density from the Global Wood Density database [19] and expansion factor of 1.4. For cases where species-specific wood 


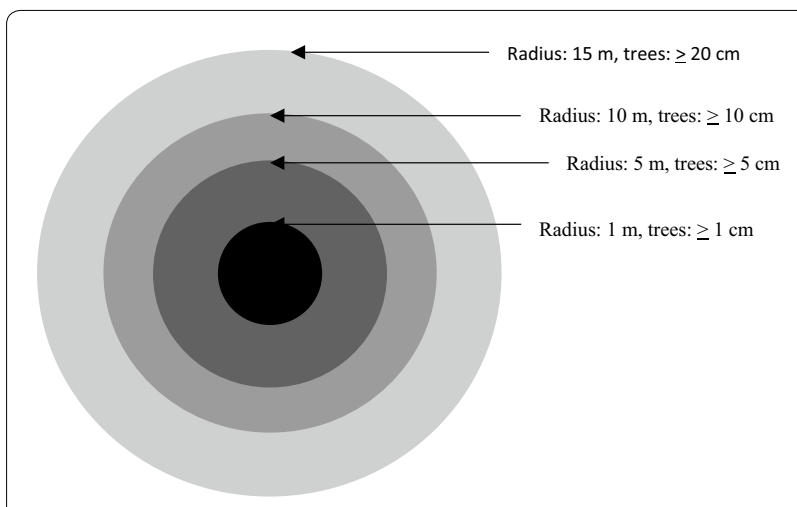

Fig. 4 Layout of concentric sample plot

density values were missing from the database, a default wood density value of $500 \mathrm{~kg} \mathrm{~m}^{-3}$ [9] was applied. BGB for some species including. Adansonia digitata, Grevillea robusta, Eucalyptus spp., Dalbergia melanoxylon, Anacardium occidentale and others could not be estimated directly using appropriate allometric BGB models. For such species BGB was estimated indirectly using a root to shoot ratio of 0.25 [20].

\section{Dwb}

DWB was estimated as the product of volume and specific wood density. Volume was computed using Smalian formula. The same procedures for conversion of tree volume to biomass were applied in conversion of dead wood volume to DWB although this did not involve the use of expansion factor. Irrespective of species, a wood density reduction factor of 0.97 was used for solid woods and 0.45 was used for the more decayed wood [10].

\section{Expansion of Tree AGB, BGB and DWB to plot level}

Expansion of tree AGB and BGB; and DWB to plot level considered the concentric plot design (Fig. 4).

AGB, BGB and DWB plot values were obtained using the Eq. 4:

$$
Y_{j}=\frac{\sum_{k \varepsilon j} \hat{Y}_{i}}{a_{i}}
$$

where $Y_{j}$ is AGB, BGB or DWB per hectare of a plot $j ; \hat{Y}_{i}$ is $\mathrm{AGB}, \mathrm{BGB}$ or DWB of a tree $i$ in plot $j$; and $a_{i}$ is inclusion area (area of sub-plot $s$ ) of tree $i$ in plot $j$.

\section{Estimation of carbon pools values of land cover sub-classes} The carbon pool values for the different land cover sub-classes (Table 1) were computed from plot values obtained in previous section. To obtain these values, ExF were applied as shown in the following equation

$$
\hat{Y}_{k}=\sum_{j \in k} Y_{j} \times E x F_{p}
$$

where $j$ and $k$ correspond to every plot $j$ with land cover sub-class $k ; E x F_{p}$ plot expansion factor of stratum $p$ where plot $j$ resides.

The mean AGB, BGB or DWB per hectare for the land cover sub-class $k$ can be computed using Eq. 6 below:

$$
\bar{Y}_{k}=\hat{Y}_{k} / \hat{A}_{k}
$$

where: $\bar{Y}_{k}$ is the mean AGB, BGB or deadwood per ha in landcover sub-class $k ; \hat{Y}_{k}$ is the total AGB, BGB or DWB in land cover sub-class $k$; and $\hat{A}_{k}$ is total area of landcover sub-class $k$.

The $\mathrm{AGB}, \mathrm{BGB}$ and $\mathrm{DWB}$ values were converted to aboveground carbon (AGC), belowground carbon (BGC) and Deadwood Carbon (DWC) by multiplying the biomass by the default IPCC carbon fraction value of 0.47 [10].

\section{Aggregation of carbon pools values from sub-classes to primary classes}

The sub-classes for the primary land cover classes were further aggregated into primary land cover classes level (i.e. forest, non-forest and wetland). The carbon pools values of each primary land cover class were estimated as a mean of the land cover sub-class estimates, which were weighted by their corresponding areas. The carbon pool value of a given primary land cover class was therefore computed using Eq. (7).

$$
Y_{M}=\frac{\sum_{k=1}^{n} Y_{k} \times \hat{A}_{k}}{\sum_{i=1}^{n} \hat{A}_{k}}
$$

where: $Y_{m}$ is the weighted estimate of AGC, BGC or DWC per hectare, $a$ is the area of land cover sub-class $k, X$ is AGC, BGC or DWC per ha of the land cover subclass and $n$ is the number of land cover sub-classes in the primary land cover class.

\section{Estimation of uncertainty for carbon stock}

Firstly, variance $\left(\sigma^{2}\right)$ for stratum $p$ was first estimated followed by estimation of Standard Error (SE) of land cover sub-class $k$ using the Eq. 8.

$$
S E_{k}=\sqrt[2]{\sum \frac{r_{p}^{2} \times S E_{p}^{2}}{n_{p}}}
$$

where: $S E_{k}$ is Standard Error of land cover sub-class $k ; \mathrm{r}_{p}$ is proportion of stratum area to total area of land cover sub-class $k ; \mathrm{SE}_{p}$ Standard Error of stratum $p ; n_{\mathrm{p}}$ number of sampling units for $p^{\text {th }}$ stratum. 
Confidence Interval $(\mathrm{X})$ of the mean for a land cover sub-class $k$ was computed using the Eq. 9.

$$
X_{k}=S E_{k} \times t
$$

where: $C I_{k}$ is Confidence Interval of the mean; $S E_{k}$ is the stratum Standard Error and $t$ is value read from $t$-distribution table at $95 \%$ confidence level.

Estimation of uncertainty of the carbon stock in each primary land cover followed the procedure described in Eq. 3.2 of IPCC [10] (Eq. 10). Errors were weighted and propagated for parameters with the same units of measurement. where: $U_{\text {total }}=$ percentage uncertainty of the sum of quantities (half the 95\% confidence interval, divided by the total (i.e. the mean) and expressed as a percentage). The term "uncertainty" is based on the $95 \%$ confidence interval. $\mathrm{X}_{\mathrm{i}}$ and $U_{\mathrm{i}}=$ uncertainty quantity and the associated percentage uncertainties, respectively.

\section{Results}

Carbon stocks for different land cover types

The average carbon stocks for the three carbon pools (AGC (t C ha $\left.{ }^{-1}\right)$, BGC ( $\left.\mathrm{t} \mathrm{ha}{ }^{-1}\right)$ and DWC $\left.\left(\mathrm{t} \mathrm{C} \mathrm{ha}^{-1}\right)\right)$

$$
U_{\text {total }}=\frac{\sqrt{\left(U_{1} \times X_{1}\right)^{2}+\left(U_{2} \times X_{2}\right)^{2}+\cdots+\left(U_{n} \times X_{n}\right)^{2}}}{\left|X_{1}+X_{2}+\cdots+X_{n}\right|}
$$

\begin{tabular}{|c|c|c|c|c|c|c|}
\hline $\begin{array}{l}\text { Primary } \\
\text { land cover } \\
\text { class }\end{array}$ & Land cover sub-class & Area (ha) & $\mathrm{AGC}\left(\mathrm{tCha} \mathrm{Ch}^{-1}\right)$ & $\mathrm{BGC}\left(\mathrm{tC} \mathrm{ha} \mathrm{C}^{-1}\right)$ & DWC $\left(\mathrm{tC} \mathrm{ha}^{-1}\right)$ & $\begin{array}{l}\text { Total } \\
\text { carbon } \\
(\mathrm{tC} \mathrm{ha}\end{array}$ \\
\hline Forest & Forest: Plantation & $543,025.2$ & 20.0 & 4.8 & 0.4 & 25.2 \\
\hline Forest & Forest: Mangrove & $158,404.6$ & 34.3 & 32.9 & 11.7 & 78.9 \\
\hline Forest & Forest: Humid Montane & $953,866.4$ & 62.0 & 15.5 & 4.8 & 82.4 \\
\hline Forest & Forest: Lowland & $1,663,340.3$ & 43.7 & 10.9 & 3.4 & 58.0 \\
\hline Forest & Woodland: Closed (> 40\%) & $9,006,125.9$ & 32.4 & 13.9 & 1.6 & 47.8 \\
\hline Forest & Woodland: Open (10-40\%) & $36,219,223.5$ & 20.0 & 8.8 & 1.1 & 29.9 \\
\hline Forest & Cultivated land (Wooded crops): Mixed tree cropping & $148,306.2$ & 18.1 & 4.5 & 2.1 & 24.7 \\
\hline Forest & Cultivated land: Wooded crops & $1,493,112.2$ & 10.9 & 3.5 & 0.7 & 15.1 \\
\hline Forest & $\begin{array}{l}\text { Woodland: Scattered crop woodland (unspecified } \\
\text { density) (wooded crops) }\end{array}$ & $2,518,260.2$ & 9.0 & 4.2 & 0.8 & 14.0 \\
\hline Forest & Bushland: Thicket & $951,895.3$ & 6.3 & 1.578 & 0.5 & 8.4 \\
\hline Forest & Bushland: Thicket with emergent trees & $303,396.0$ & 14.7 & 8.1 & 2.2 & 25.0 \\
\hline Non forest & Bushland: Dense & $1,961,501.5$ & 9.0 & 2.2 & 0.6 & 11.8 \\
\hline Non forest & Bushland: Emergent trees & $320,526.0$ & 9.3 & 5.1 & 1.0 & 15.4 \\
\hline Non forest & Bushland: Open & $2,796,873.4$ & 10.0 & 4.0 & 0.2 & 14.3 \\
\hline Non forest & Bushland: Scattered cultivation & $1,139,605.7$ & 7.1 & 4.5 & 0.9 & 12.5 \\
\hline Non forest & Cultivated land: Agro-forestry system & $1,352,158.0$ & 4.0 & 1.0 & 0.5 & 5.5 \\
\hline Non forest & Cultivated land: Grain crops & $9,748,899.9$ & 2.5 & 0.6 & 0.2 & 3.3 \\
\hline Non forest & Cultivated land: Herbaceous crops & $4,971,302.0$ & 2.4 & 0.6 & 0.7 & 3.6 \\
\hline Non forest & Grassland: Bushed & $433,078.4$ & 3.3 & 1.4 & 0.1 & 4.8 \\
\hline Non forest & Grassland: Open & $3,115,798.5$ & 0.3 & 0.1 & 0.03 & 0.3 \\
\hline Non forest & Grassland: Scattered cropland & $582,387.0$ & 1.5 & 0.8 & 0.4 & 2.7 \\
\hline Non forest & Grassland: Wooded & $4,667,016.0$ & 4.8 & 2.2 & 0.2 & 7.2 \\
\hline Non forest & Not classified & 4903.9 & 3.4 & 0.8 & 0.0 & 4.2 \\
\hline Non forest & Open land: Bare soil & $159,354.4$ & 2.0 & 0.5 & 1.2 & 3.7 \\
\hline Non forest & Open land: Rock outcrops & $94,368.6$ & 4.8 & 1.2 & 0.1 & 6.0 \\
\hline Non forest & Open land: Salt crusts & $17,807.6$ & 1.6 & 0.4 & 0.0 & 2.0 \\
\hline Non forest & Other areas & $1,861,784.0$ & 5.4 & 1.3 & 0.5 & 7.2 \\
\hline wetland & Water: Inland water & $149,490.0$ & 4.9 & 1.2 & 1.9 & 7.9 \\
\hline wetland & Water: Swamp & $998,490.1$ & 2.7 & 0.7 & 0.3 & 3.7 \\
\hline
\end{tabular}

Table 2 Area coverage and average carbon stock in three IPCC pools for different land cover classes 
for each of the Land cover sub-class are presented in (Table 2). The areas of the respective land cover sub-class before aggregation into the primary vegetation sub-class are also presented in Table 2. The average total carbon stocks for aggregated land cover sub-classes (vegetation types) were computed and presented in Table 3. The values of the land cover sub classes ranged from 12.40 to $78.8 \mathrm{t} \mathrm{C} \mathrm{ha}^{-1}$. The highest value was observed in mangrove while the lowest value was for thicket and wetland. When aggregating the land cover sub classes into primary land cover, the total carbon stock values for the three pools were ranging from $4.28 \mathrm{t} \mathrm{C}$ ha- 1 to $33.35 \mathrm{t} \mathrm{C} \mathrm{ha}^{-1}$. Uncertainty analysis was also done in line with the IPCC requirements. Among the three primary vegetation classes, wetland had higher uncertainty values of the carbon stock estimates compared to forest and non-forest class.

\section{Discussion}

The overall objective of this paper was to compute carbon stocks for different land cover types of Mainland Tanzania using NFI (i.e. NAFORMA) data, which was conducted over a 5-year period of 2009 and 2014 by the Tanzania Forest Agency.

NAFORMA field plots cover all the land categories, making assessment of the areas and area change of all IPCC land categories and carbon pools possible. In this study carbon estimates have been reported for three IPCC carbon pools which included, above ground, below ground and deadwood. These pools are selected because, data have been collected on them through ground surveys as part of NAFORMA and, importantly, they are considered to represent the most important IPCC carbon pools for REDD+ reporting purposes. Based on this, total carbon was computed based on the three IPCC carbon pools as presented in Tables 2 and 3. Of all the land cover sub-classes, mangrove, lowland and humid

Table 3 Average total carbon stocks and uncertainties for different aggregated land cover sub-classes

\begin{tabular}{|c|c|c|}
\hline Land cover sub-classes & Carbon $\left(\mathrm{t} \mathrm{Cha} \mathrm{C}^{-1}\right)$ & Uncertainty (\%) \\
\hline Forest: Closed woodland (> 40\%) & 47.82 & 0.62 \\
\hline Forest: Open woodland (10-40\%) & 29.93 & 1.24 \\
\hline Forest: Plantation & 25.19 & 1.44 \\
\hline Forest: Mangrove & 78.86 & 0.78 \\
\hline Forest: Montane and lowland & 66.90 & 1.56 \\
\hline Forest:Thickets & 12.40 & 1.34 \\
\hline Forest: Wooded crops & 14.77 & 4.34 \\
\hline Overall for forest & 33.35 & 0.93 \\
\hline Wetland & 4.28 & 11.3 \\
\hline Non-forest & 5.81 & 1.8 \\
\hline
\end{tabular}

montane forests had relatively higher total carbon estimates compared to other categories. This may be attributed by the presence of large trees in terms of $\mathrm{dbh}$ and height as compared to other land cover sub categories (Table 2). According to Brown et al. [21], large size trees tend to account for a large proportion of the AGB in mature forests; often between 30 and $40 \%$ of the AGB can be found in trees with diameters greater than $70 \mathrm{~cm}$. On the other hand, lower values in other categories such as savanna may be attributed by the nature of the tree species as well as exposure different threats such as fire and selective logging. Generally, the carbon estimates presented for different categories reflect the carbon estimates values of the specific vegetation type for the precision intended at the national scale. There might be small deviations with the previous results reported in MNRT [9]. Given that the same dataset was used previously and reported in MNRT (2015) as well as the current study, the results presented in this paper are different from those reported previously in MNRT [9]. The noted differences may be attributed to the use of newly developed allometric models [See 17, 18], which are National and land cover specific. Specific vegetation type allometric models and direct biomass estimation approach are likely to be less biased and have smaller residual standard errors [22, 23 ] which may reduce error propagation at different scale of forest inventory.

In the previous reports, e.g. [9] estimation of biomass was done by indirect method as the product of wood density and tree stem volume. This was attributed by the lack of allometric models which were under construction at that time [see 13]. According to Njana [24] the use of indirect methods may results into large uncertainties of AGB estimates compared to the use tree allometric models. Thus the values presented in this paper may be highly relevant for REDD+ reporting as compared to the values reported in MNRT [9] and may be of interest for understanding the forest resources of Tanzania and their distribution across different land cover types at the National Scales. Results reported in our paper may also be different from reported case studies, such differences are attributable to scale (sub-national and national) and sampling design employed. However, if sampling employed is appropriate the margin of differences in estimates is not very large. There might be variations also in carbon estimates which results from the differences in the sampling design. As previously mentioned NAFORMA data was intended for generating the estimates of forest attributes at the national level precision, and thus may not capture much of the local variability presented by other studies. But since REDD+ reporting so far is currently aimed at the National scales the NAFORMA estimates are more appropriate. However, if NAFORMA has to be used for 
small area estimations, options for enhancing the precision using auxiliary remote sensing data will be the obvious choice [13]. Such approach is widely accepted as the best way of using NFI data for local based reporting [see 25-27].

Aggregation of the Land cover sub-classes to a more homogeneous classes was done to have larger number of sample units per respective category but also to be in line with categories which are used for reporting activity data in the country. Carbon stocks for respective aggregated land cover sub-classes are presented in Table 3. Mangrove seemed to have large values of average total carbon stock compared to other categories, this could be explained by large amount DWC in mangrove forests. The overall average carbon stock for the three major categories, i.e. forest, wetland and non-forest are less than the IPCC default values which range from 56 to $200 \mathrm{t} \mathrm{C} \mathrm{ha}^{-1}$ for AGC. Most of the values reported in our paper fall below the lower-end of this range however the country specific estimates are considered to be more accurate and more appropriate to use. Thus in the context of IPCC levels of methodology, the reporting values of carbon stocks will support the country to report carbon emission at Tier 3 which essentially uses country-specific data (i.e. National inventory and allometric biomass models). The reported estimates also serve the purpose of forest carbon monitoring, either as an initial inventory of stocks from which changes can be estimated based on knowledge of effects of different factors such as harvesting and natural disturbances, or as a direct estimate of stock change from repeated inventories.

Uncertainty estimates are an essential element of a complete inventory of greenhouse gas emissions and removals. They should be derived for both the national level and the trend estimate, as well as for the component parts such as emission factors, activity data and other estimation parameters for each category. In this study we presented analysis of uncertainty which are within the bound of our expectations. There is high uncertainty in wetland, given the high variability of carbon stock in this category but also may be attributed by small number of field plots on this category as compared to forest and non-forest categories. However, generally the values of uncertainties for the three classes are within the reasonable ranges. As such they can be used for accounting the uncertainty for carbon emission factors elsewhere but also for computing overall uncertainty of carbon emission in construction of FREL for REDD+.

\section{Conclusion}

In this paper, we have demonstrated that NFI data can be used for estimation of carbon stock for different land cover types. The study also demonstrate carbon stored in non-forestland. Non-forestland represents a land cover remaining after deforestation according to the national forest definition. Mangrove, lowland and humid montane forests store large quantities of carbon per unit area, if such forestlands are converted to non-forestland they lead into large emissions. Equally, in addition to large area occupied, woodlands also store large quantities of carbon. For the purpose of reducing emissions from deforestation and by considering national circumstances, all land covers should be managed although the management intensity and priorities should consider the significance emissions and other utilities such as biodiversity. The values presented in this paper correspond to IPCC tier 3 and can be used for estimation of land cover specific emission factors for and subsequently use emission factors to derive FREL for REDD+. However, if local based estimates values are needed, use of auxiliary data to enhance the precision of the area of interest should be considered.

\begin{abstract}
Abbreviations
REDD+: reducing emissions from deforestation and forest degradation; FREL: forest reference emission level; NFI: national forest inventory; NAFORMA: National Forest Resources Monitoring and Assessment; AGB: above ground biomass; BGB: below ground biomass; DWB: dead wood.
\end{abstract}

\section{Authors' contributions}

EWM has been involved in designing the study, drafting the manuscript, data analysis and write up. WAM and MAN performed analysis and revised the manuscript. EZ and REM revised the manuscript. All authors read and approved the final manuscript.

\section{Author details \\ ${ }^{1}$ Department of Forest Engineering and Wood Sciences, College of Forestry, Wildlife and Tourism, Sokoine University of Agriculture, Box 3012, Morogoro, Tanzania. ${ }^{2}$ Department of Forest Resources Assessment and Management, College of Forestry, Wildlife and Tourism, Sokoine University of Agriculture, Box 3013, Morogoro, Tanzania. ${ }^{3}$ National Carbon Monitoring Centre, Box 3013, Morogoro, Tanzania.}

\section{Acknowledgements}

The authors are grateful to Tanzania Forest Service for allowing the use NAFORMA data in this study. Authors are also grateful for contributions from research Professor Johannes Breidenbach of Norwegian Institute of Bioeconomy Research (NIBIO) who read and commented on the draft manuscript.

\section{Competing interests}

The authors declare that they have no competing interests.

\section{Availability of data and materials}

All authors declare that the datasets used in this manuscript are available upon request from Tanzania Forest Service.

\section{Funding}

The financial support for this research was provided by National Carbon Monitoring Centre (NCMC) of Tanzania.

Consent for publication

Not applicable.

Ethics approval and consent to participate

Not applicable. 


\section{Appendix 1: Allometric AGB, volume and BGB} models for different land cover classes in Mainland

Tanzania

Appendix 1a

See Table 4.

Table 4 Allometric AGB models for different land cover classes in Mainland Tanzania

\begin{tabular}{|c|c|c|c|}
\hline Land cover sub-class & Species & AGB & Source \\
\hline Forest: Humid Montane & All & $0.3571 \times \mathrm{dbh}^{1.744} \times \mathrm{ht}^{0.4713}$ & [28] \\
\hline Forest: Lowland & All & $0.3571 \times \mathrm{dbh}^{1.744} \times \mathrm{ht}^{0.4713}$ & {$[28]$} \\
\hline \multirow[t]{4}{*}{ Forest: Mangrove } & Avicenia marina & $0.25128 \times \mathrm{dbh}^{2.24351}$ & [29] \\
\hline & Soneratia alba & $0.25128 \times \mathrm{dbh}^{2.21727}$ & [29] \\
\hline & Rhizophora mucronata & $0.25128 \times \mathrm{dbh}^{2.26026}$ & [29] \\
\hline & Others & $0.19633 \times \mathrm{dbh}^{2.010853} \times \mathrm{ht}^{0.29654}$ & [29] \\
\hline \multirow[t]{2}{*}{ Forest: Plantation } & Tectona grandis & $0.1711 \times \mathrm{dbh}^{2.0047} \times \mathrm{ht}^{0.3767}$ & {$[30]$} \\
\hline & Pinus patula & $0.0550 \times \mathrm{dbh}^{2.5968}$ & [31] \\
\hline \multirow[t]{2}{*}{ Woodland: Closed (> 40\%) } & All & $0.0763 \times \mathrm{dbh}^{2.2046} \times \mathrm{ht}^{0.4918}$ & [23] \\
\hline & Baobab & $2.234966 \times \mathrm{dbh}^{1.43543}$ & [32] \\
\hline \multirow[t]{2}{*}{ Woodland: Open (10-40\%) } & All & $0.0763 \times \mathrm{dbh}^{2.2046} \times \mathrm{ht}^{0.4918}$ & [23] \\
\hline & Baobab & $2.234966 \times \mathrm{dbh}^{1.43543}$ & [32] \\
\hline \multirow[t]{3}{*}{ Bushland: Thicket, dense } & Pseudoprosopis fischeri & $0.4276 \times \mathrm{dbh}^{2.4053} \mathrm{st}^{0.5290}$ & [33] \\
\hline & Combretum celastroides & $0.7269 \times \mathrm{dbh}^{2.6710} \times \mathrm{ht}^{0.5737} \mathrm{st}^{0.2039}$ & [33] \\
\hline & Baobab & $2.234966 \times \mathrm{dbh}^{1.43543}$ & [32] \\
\hline Bushland: Emergent trees & All & $1.2013 \times \mathrm{dbh}^{1.5076}$ & [33] \\
\hline Bushland: Thicket with emergent trees & All & $1.2013 \times \mathrm{dbh}^{1.5076}$ & {$[33]$} \\
\hline \multirow{2}{*}{ Bushland: Open } & Others & $0.0763 \times \mathrm{dbh}^{2.2046} \times \mathrm{ht}^{0.4918}$ & [23] \\
\hline & Acacia and Commiphora spp. & $0.0292 \times \mathrm{dbh}^{2.0647} \times \mathrm{ht}^{1.0146}$ & [34] \\
\hline \multirow[t]{3}{*}{ Grassland:Wooded } & Others & $0.0763 \times \mathrm{dbh}^{2.2046} \times \mathrm{ht}^{0.4918}$ & [23] \\
\hline & Acacia and Commiphora spp. & $0.0292 \times \mathrm{dbh}^{2.0647} \times \mathrm{ht}^{1.0146}$ & [34] \\
\hline & Baobab & $2.234966 \times \mathrm{dbh}^{1.43543}$ & [32] \\
\hline \multirow{3}{*}{$\begin{array}{l}\text { Grassland: Bushed } \\
\text { Grassland: Open }\end{array}$} & Others & $0.0763 \times \mathrm{dbh}^{2.2046} \times \mathrm{ht}^{0.4918}$ & [23] \\
\hline & Acacia and Commiphora spp. & $0.0292 \times \mathrm{dbh}^{2.0647} \times \mathrm{ht}^{1.0146}$ & [34] \\
\hline & Baobab & $2.234966 \times \mathrm{dbh}^{1.43543}$ & [32] \\
\hline \multirow{2}{*}{$\begin{array}{l}\text { Woodland: Scattered cropland (Unspecified } \\
\text { density) }\end{array}$} & All & $0.0763 \times \mathrm{dbh}^{2.2046} \times \mathrm{ht}^{0.4918}$ & [23] \\
\hline & Baobab & $2.234966 \times \mathrm{dbh}^{1.43543}$ & {$[32]$} \\
\hline \multirow[t]{2}{*}{ Bushland: Scattered cultivation } & All & $1.2013 \times \mathrm{dbh}^{1.5076}$ & {$[33]$} \\
\hline & Baobab & $2.234966 \times \mathrm{dbh}^{1.43543}$ & {$[33]$} \\
\hline Grassland: Scattered cropland & All & $1.2013 \times \mathrm{dbh}^{1.5076}$ & [33] \\
\hline Cultivated land: Agro-forestry system & All & $0.051 *\left(\mathrm{dbh} \mathrm{h}^{2 *} \mathrm{ht}\right)^{0.93}$ & [35] \\
\hline \multirow[t]{3}{*}{ Cultivated land: Wooded crops } & Coconut trees & $3.7964 \times \mathrm{ht}^{1.8130}$ & [36] \\
\hline & Cashew nut trees & $0.3152 \times \mathrm{dbh}^{1.7722} \mathrm{ht}^{0.5003}$ & [37] \\
\hline & Others & $0.0763 \times \mathrm{dbh}^{2.2046} \times \mathrm{ht}^{0.4918}$ & [23] \\
\hline Cultivated land: Herbaceous crops & All & $0.051^{*}\left(\mathrm{dbh} \mathrm{h}^{2 *} \mathrm{ht}\right)^{0.93}$ & [35] \\
\hline Cultivated land: Mixed tree cropping & All & $0.051 *\left(\mathrm{dbh}^{2 *} \mathrm{ht}\right)^{0.93}$ & {$[35]$} \\
\hline Cultivated land: Grain crops & All & $0.051 *\left(\mathrm{dbh}^{2 *} \mathrm{ht}\right)^{0.93}$ & {$[35]$} \\
\hline
\end{tabular}


Appendix 1b

See Table 5.

Table 5 Allometric volume models for different land cover classes in Mainland Tanzania

\begin{tabular}{|c|c|c|c|}
\hline Land cover sub-class & Species & Volume $\left(\mathrm{m}^{3}\right)$ & Source \\
\hline \multirow[t]{3}{*}{ Forest: Plantation } & Eucalyptus spp. & $0.000065 \times \mathrm{dbh}^{1.633} \mathrm{ht}^{1.137}$ & {$[38]$} \\
\hline & Grevillea robusta & $0.000065 \times \mathrm{dbh}^{1.633} \mathrm{ht}^{1.137}$ & [38] \\
\hline & Others & $0.5 \times 3.14 \times(0.01 \times \mathrm{dbh} / 2)^{2} \times \mathrm{ht}$ & [39] \\
\hline Woodland: Closed (> 40\%) & Dalbergia melanoxylon & $0.00023 \times \mathrm{dbh}^{2.231}$ & Malimbwi 2000 \\
\hline Woodland: Open (10-40\%) & Dalbergia melanoxylon & $0.00023 \times \mathrm{dbh}^{2.231}$ & Malimbwi 2000 \\
\hline Open land: Bare soil & All & $0.5 \times 3.14 \times(0.01 \times \mathrm{dbh} / 2)^{2} \times \mathrm{ht}$ & {$[39]$} \\
\hline Open land: Salt crusts & All & $0.5 \times 3.14 \times(0.01 \times \mathrm{dbh} / 2)^{2} \times \mathrm{ht}$ & [39] \\
\hline Open land: Rock outcrops & All & $0.5 \times 3.14 \times(0.01 \times \mathrm{dbh} / 2)^{2} \times \mathrm{ht}$ & [39] \\
\hline Water: Inland water & All & $0.5 \times 3.14 \times(0.01 \times \mathrm{dbh} / 2)^{2} \times h t$ & [39] \\
\hline Water: Swamp & All & $0.5 \times 3.14 \times(0.01 \times \mathrm{dbh} / 2)^{2} \times \mathrm{ht}$ & [39] \\
\hline Other areas & All & $0.5 \times 3.14 \times(0.01 \times \mathrm{dbh} / 2)^{2} \times \mathrm{ht}$ & [39] \\
\hline
\end{tabular}

\section{Appendix 1c}

See Table 6.

Table 6 Allometric BGB models for different land cover classes in Mainland Tanzania

\begin{tabular}{|c|c|c|c|}
\hline Land cover sub-class & Species & $\mathrm{BGB}$ & Source \\
\hline \multirow[t]{4}{*}{ Forest: Mangrove } & Avicenia marina & $1.42040 \times \mathrm{dbh}^{1.44260}$ & [29] \\
\hline & Soneratia alba & $1.42040 \times \mathrm{dbh}^{1.65760}$ & {$[29]$} \\
\hline & Rhizophora mucronata & $1.42040 \times \mathrm{dbh}^{1.68979}$ & {$[29]$} \\
\hline & Others & $1.42040 \times \mathrm{dbh}^{1.59666}$ & {$[29]$} \\
\hline \multirow[t]{2}{*}{ Forest: Plantation } & Tectona grandis & $0.0279 \times \mathrm{dbh}^{1.7430} \times \mathrm{ht}^{0.7689}$ & {$[30]$} \\
\hline & Pinus patula & $0.0027 \times \mathrm{dbh}^{3.0579}$ & {$[31]$} \\
\hline \multirow[t]{3}{*}{ Woodland: Closed (>40\%) } & All & $0.1766 \times \mathrm{dbh}^{1.7844} \mathrm{ht}^{0.3434}$ & {$[23]$} \\
\hline & Baobab & $A G B \times 0.25$ & {$[32]$} \\
\hline & Dalbergia melanoxylon & $A G B \times 0.25$ & [9] \\
\hline Woodland: Open (10-40\%) & All & $0.1766 \times \mathrm{dbh}^{1.7844} \mathrm{ht}^{0.3434}$ & {$[23]$} \\
\hline \multirow[t]{2}{*}{ Bushland: Thicket, dense } & Pseudoprosopis fischeri & $0.1442 \times \mathrm{dbh}^{4.1534} \mathrm{st}^{0.4117}$ & {$[33]$} \\
\hline & Combretum celastroides & $0.1006 \times \mathrm{dbh}^{4.0062} \mathrm{st}^{0.33499}$ & {$[33]$} \\
\hline Bushland: Emergent trees & All & $1.3803 \times \mathrm{dbh}^{1.1671}$ & {$[33]$} \\
\hline Bushland: Thicket with emergent trees & All & $1.3803 \times \mathrm{dbh}^{1.1671}$ & {$[33]$} \\
\hline \multirow[t]{2}{*}{ Bushland: Open } & Others & $0.1766 \times \mathrm{dbh}^{1.7844} \mathrm{ht}^{0.3434}$ & {$[23]$} \\
\hline & Acacia and Commiphora spp. & $0.0593 \times \mathrm{dbh}^{1.4481} \times \mathrm{ht}^{1.0210}$ & {$[34]$} \\
\hline \multirow[t]{2}{*}{ Grassland: Wooded } & Others & $0.1766 \times \mathrm{dbh}^{1.7844} \mathrm{ht}^{0.3434}$ & {$[23]$} \\
\hline & Acacia and Commiphora spp. & $0.0593 \times \mathrm{dbh}^{1.4481} \times \mathrm{ht}^{1.0210}$ & {$[34]$} \\
\hline \multicolumn{4}{|l|}{ Grassland: Bushed } \\
\hline \multirow[t]{2}{*}{ Grassland: Open } & Others & $0.1766 \times \mathrm{dbh}^{1.7844} \mathrm{ht}^{0.3434}$ & {$[23]$} \\
\hline & Acacia and Commiphora spp. & $0.0593 \times \mathrm{dbh}^{1.4481} \times \mathrm{ht}^{1.0210}$ & {$[34]$} \\
\hline Woodland: Scattered cropland (Unspecified density) & All & $0.1766 \times \mathrm{dbh}^{1.7844} \mathrm{ht}^{0.3434}$ & {$[23]$} \\
\hline \multirow[t]{2}{*}{ Bushland: Scattered cultivation } & All & $1.3803 \times \mathrm{dbh}^{1.1671}$ & {$[33]$} \\
\hline & Baobab & $A G B \times 0.25$ & {$[33]$} \\
\hline Grassland: Scattered cropland & All & $1.3803 \times \mathrm{dbh}^{1.1671}$ & {$[33]$} \\
\hline \multirow[t]{2}{*}{ Cultivated land: Wooded crops } & Coconuts trees & $13.5961 \times h t^{0.6635}$ & {$[36]$} \\
\hline & Others & $0.1766 \times \mathrm{dbh}^{1.7844} \mathrm{ht}^{0.3434}$ & {$[23]$} \\
\hline
\end{tabular}




\section{Publisher's Note}

Springer Nature remains neutral with regard to jurisdictional claims in published maps and institutional affiliations.

Received: 17 January 2019 Accepted: 19 April 2019

Published online: 27 April 2019

\section{References}

1. Sasaki N, Chheng K, Mizoue N, Abe I, Lowe AJ. Forest reference emission level and carbon sequestration in Cambodia. Global Ecol Conserv. 2016;7:82-96.

2. Pelletier J, Goetz SJ. Baseline data on forest loss and associated uncertainty: advances in national forest monitoring. Environ Res Lett. 2015;10:021001.

3. Romijn E, Herold M, Kooistra L, Murdiyarso D, Verchot L. Assessing capacities of non-annex i countries for national forest monitoring in the context of REDD+. Environ Sci Policy. 2012:19:33-48.

4. Angelsen A. Realising redd+: national strategy and policy options. Bogor: CIFOR; 2009.

5. FAO. Emerging approaches to Forest Reference Emission Levels and/ or Forest Reference Levels for REDD+. The UNREDD Programme 2014 http://www.unredd.net/index.phpoption=com_docman\&task=doc_ download\&gid =13469\&ltemid=53. Accessed 20 May 2018 .

6. Maniatis D, Mollicone D. Options for sampling and stratification for national forest inventories to implement REDD+ under the UNFCCC. Car Bal Manage. 2010;5:9

7. Eggleston S, Buendia L, Miwa K. 2006 ipcc guidelines for national greenhouse gas inventories [recurso electrónico]: Waste. Kanagawa: Institute for Global Environmental Strategies; 2006.

8. Pedroni L, Dutschke M, Streck C, Porrua ME. Creating incentives for avoiding further deforestation: the nested approach. Clim Change For 2009:9(2):207-20.

9. MNRT. National Forest Resources Monitoring and Assessment of Tanzania mainland (NAFORMA). Main results. 2015, p. 106.

10. IPCC. Agriculture, Forestry and other Land use. In: Eggleston HS, Buendia L, Miwa K, Ngara T, Tanabe K, eds. IPCC guidelines for national greenhouse gas inventories. Prepared by the national greenhouse gas inventories programme, institute for global environmental strategies (iges), Hayama, Japan. 2006.

11. Burgess N, Hales JA, Underwood E, Dinerstein E, Olson D, Itoua I, Schipper J, Ricketts T, Newman K. Terrestrial ecoregions of Africa and Madagascar: a conservation assessment. Washington: Island Press; 2004.

12. MNRT. National definition of "Forest" for REDD + and CDM in Tanzania. Dar es Salaam: Ministry of Natural Resources and Tourism; 2016. p. 10.

13. Tomppo E, Malimbwi R, Katila M, Mäkisara K, Henttonen HM, Chamuya N, Zahabu E, Otieno J. A sampling design for a large area forest inventory: case Tanzania. Can J For Res. 2014;44:931-48.

14. Tomppo E, Katila M, Makisara K, Malimbwi R, Chamuya N, Otieno J, Dalsgaard S, Leppanen M. A report to the Food and Agriculture Organization of the United Nations (FAO) in support of sampling study for National Forestry Resources Monitoring and Assessment (NAFORMA) in Tanzania. 2010.

15. Cochran WG. Sampling techniques-3. 1977.

16. Vesa L, Malimbwi R, Tomppo E, Zahabu E, Maliondo S, Chamuya N, Nssoko E, Otieno J, Miceli G, Kaaya A. NAFORMA field manual Biophysical survey. Dar es Salaam: Forestry and Beekeeping Division, Ministry of Natural Resources and Tourism; 2010. p. 96.

17. Malimbwi R, Eid T, Chamshama S. Allometric tree biomass and volume models in Tanzania. Morogoro: Department of Forest Mensuration and Management, Sokoine University of Agriculture; 2018.

18. URT. Tanzani's forest reference emission level submission to the UNFCCC. 2017, 56.

19. Zanne A, Lopez-Gonzalez G, Coomes D, Ilic J, Jansen S, Lewis S, Miller R, Swenson N, Wiemann M. Chave J. Global wood density database. 2009.

20. Mokany K, Raison RJ, Prokushkin AS. Critical analysis of root: shoot ratios in terrestrial biomes. Glob Change Biol. 2006:12:84-96.

21. Brown S, Schroeder P, Birdsey R. Aboveground biomass distribution of us eastern hardwood forests and the use of large trees as an indicator of forest development. For Ecol Manage. 1997;96:37-47.
22. Mauya EW, Mugasha WA, Zahabu E, Bollandsås OM, Eid T. Models for estimation of tree volume in the miombo woodlands of Tanzania. S For J For Sci. 2014:76:209-19.

23. Mugasha WA, Eid T, Bollandsås OM, Malimbwi RE, Chamshama SAO, Zahabu E, Katani JZ. Allometric models for prediction of above-and belowground biomass of trees in the miombo woodlands of Tanzania. For Ecol Manage. 2013;310:87-101.

24. Njana MA. Indirect methods of tree biomass estimation and their uncertainties. S For J For Sci. 2017:79:41-9.

25. McRoberts RE, Tomppo EO. Remote sensing support for national forest inventories. Remote Sens Environ. 2007;110:412-9.

26. McRoberts RE, Tomppo EO, Næsset E. Advances and emerging issues in national forest inventories. Scand J For Res. 2010;25:368-81.

27. Tomppo E, Olsson H, Ståhl G, Nilsson M, Hagner O, Katila M. Combining national forest inventory field plots and remote sensing data for forest databases. Remote Sens Environ. 2008;112:1982-99.

28. Mugasha WA, Mwakalukwa EE, Luoga E, Malimbwi RE, Zahabu E, Silayo DS, Sola G, Crete P, Henry M, Kashindye A. Allometric models for estimating tree volume and aboveground biomass in lowland forests of Tanzania. Int J For Res. 2016;2016:1-3.

29. Njana MA, Bollandsås OM, Eid T, Zahabu E, Malimbwi RE. Above-and belowground tree biomass models for three mangrove species in Tanzania: a nonlinear mixed effects modelling approach. Ann For Sci. 2016:73:353-69.

30. Zahabu E, Mugasha W, Katani J, Malimbwi R, Mwangi J, Chamshama S. Allometric biomass and volume models for tectona grandis plantations. In: Malimbwi R, Eid T, Chamshama SAO, editors. Allometric tree biomass and volume models in Tanzania, Department of forest resources assessment and management. Morogoro: Sokoine University of Agriculture; 2018. p. 147.

31. Mugasha A, Zahabu E, Maguta M, Mshana J, Katani J, Chamshama S. Allometric biomass models for pinus patula plantations. In: Malimbwi R, Eid T, Chamshama SAO, editors. Allometric tree biomass and volume models in Tanzania. Morogoro: Department of forest resources assessment and management, Sokoine University of Agriculture; 2018. p. 147.

32. Masota A, Zahabu E, Malimbwi R. Allometric biomass and volume models for Baobab trees. In: Malimbwi R, Eid T, Chamshama SAO, editors. Allometric tree biomass and volume models in Tanzania. Morogoro: Department of forest resources assessment and management, Sokoine University of Agriculture; 2018. p. 147.

33. Makero J, Malimbwi R, Eid T, Zahabu E. Allometric biomass and volume models for Itigi thicket. In: Malimbwi R, Eid T, Chamshama SAO, editors. Allometric tree biomass and volume models in Tanzania. Morogoro: Department of forest resources assessment and management, Sokoine University of Agriculture; 2018. p. 147.

34. Mugasha A, Zahabu E, Mathias A, Luganga H, Maliondo S, Malimbwi R. Allometric biomass and volume models for acacia-commiphora woodlands. In: Malimbwi R, Eid T, Chamshama SAO, editors. Allometric tree biomass and volume models in Tanzania. Morogoro: Department of forest resources assessment and management, Sokoine University of Agriculture; 2018. p. 147.

35. Henry M, Tittonell P, Manlay RJ, Bernoux M, Albrecht A, Vanlauwe B. Biodiversity, carbon stocks and sequestration potential in aboveground biomass in smallholder farming systems of western kenya. Agric Ecosyst Environ. 2009;129:238-52.

36. Zahabu E, Mugasha A, Malimbwi R, Katani J. Allometric biomass and volume models for coconut trees. In: Malimbwi R, Eid T, Chamshama $\mathrm{SAO}$, editors. Allometric tree biomass and volume models in Tanzania. Morogoro: Department of forest resources assessment and management, Sokoine University of Agriculture; 2018. p. 147.

37. Zahabu E, Mlagalila $H$, Katani J. Allometric biomass and volume models for cashewnut trees. In: Malimbwi R, Eid T, Chamshama SAO, editors. Allometric tree biomass and volume models in Tanzania. Morogoro: Department of forest resources assessment and management, Sokoine University of Agriculture; 2018. p. 147.

38. Malimbwi, R.; Mbwambo, Z. Local volume tables for eucalyptus grandis at Sao Hill forest project. 1990

39. Haule EF, Munyuku FC. National forest inventory in Tanzania. In: Malimbwi $\mathrm{R}$, Luoga EJ, eds. Proceedings of the workshop on information acquisition for sustainable natural forest resources of eastern, central and southern Africa, faculty of forestry, Sua, Morogoro. 1994. P. 99-113. 